\title{
KEBERLANJUTAN TRADISI PRA-ISLAM PADA PENATAAN KOTA DI CIANJUR ABAD KE-17 - 19 MASEHI
}

\author{
(Pre-Islamic Tradition Continuity of Cianjur Layout Planning During The $17^{\text {th }}-19^{\text {th }}$ \\ Century)
}

\author{
Muhamad Alnoza, dan Bagus Dimas Bramantio \\ Pascasarjana Antropologi, Fakultas Ilmu Budaya, Universitas Gadjah Mada \\ Jalan Sosiohumaniora, Bulaksumur, Sleman, D.I. Yogykarta \\ Program Studi Arkeologi, Fakultas Ilmu Pengetahuan Budaya, Universitas \\ Indonesia, Jalan Selo Soemardjan, Kampus UI, Depok, Jawa Barat \\ Pos-el : muhamadalnoza@mail.ugm.ac.id,bagus.dimas71@ui.ac.id
}

\begin{tabular}{|c|c|}
\hline INFO ARTIKEL & $A B S T R A C T$ \\
\hline $\begin{array}{l}\text { Histori Artikel } \\
\text { Diterima : September } 2021 \\
\text { Direvisi : November } 2021 \\
\text { Disetujui : November } 2021 \\
\end{array}$ & $\begin{array}{l}\text { This study discusses the application of a Sundanese cosmology called } \\
\text { tritangtu in the arrangement of the city of Cianjur. Tritangtu is a } \\
\text { concept of the existence of a universal triple pattern in all aspects of } \\
\text { human life. where the focus of this discussion is tritangtu in the world }\end{array}$ \\
\hline $\begin{array}{l}\text { Keywords: } \\
\text { Cianjur, Sundanese, } \\
\text { cosmology, tritangtu, } \\
\text { urban planing }\end{array}$ & $\begin{array}{l}\text { or "three patterns in the world". Research on the continuation of } \\
\text { urban planning from the Hindu-Buddhist period to the Islamic- } \\
\text { Colonial period has basically never been done, so that is the novelty } \\
\text { aspect of this research. The research steps used in answering the } \\
\text { formulation of the research problem include data collection, analysis, } \\
\text { interpretation. Based on the research conducted in this study, the city } \\
\text { of Cianjur has applied two cosmological concepts at two levels, } \\
\text { namely micro and macro. At the micro level, which includes the city } \\
\text { center, it is arranged according to the cosmological rules of Islamic } \\
\text { cities in Java. The spatial arrangement seen in the city of Cianjur at } \\
\text { the macro level is known to follow the rules of the tritangtu concept. } \\
\text { ABSTRAK }\end{array}$ \\
\hline $\begin{array}{l}\text { Kata Kunci: } \\
\text { Cianjur, Sunda, } \\
\text { kosmologi, tritangtu, } \\
\text { tata kota }\end{array}$ & $\begin{array}{l}\text { Penelitian ini membahas perihal penerapan kosmologis khas Sunda } \\
\text { bernama tritangtu pada penataan kota Cianjur. Tritangtu merupakan } \\
\text { suatu konsep akan adanya pola tiga universal di segala aspek } \\
\text { kehidupan manusia, dimana yang menjadi fokus dalam pembahasan } \\
\text { ini ialah tritangtu di buana atau "pola tiga di dunia". Pola tritangtu di } \\
\text { buana terdiri dari prabhu (raja), rsi (pemimpin keagamaan), dan rama } \\
\text { (tetua adat) Tujuan penelitian ini adalah mengungkap keberadaan } \\
\text { pelanjutan tradisi masa pra-Islam di Jawa Barat masa Islam-Kolonial. } \\
\text { Penelitian mengenai kelanjutan tata kota masa Hindu-Buddha ke masa } \\
\text { Islam-Kolonial selama ini pada dasarnya belum pernah dilakukan, } \\
\text { sehingga hal tersebutlah yang menjadi aspek kebaruan dari penelitian } \\
\text { ini. Langkah penelitian yang digunakan dalam menjawab rumusan } \\
\text { masalah penelitian ini, antara lain pengumpulan data, analisis, } \\
\text { interpretasi. Berdasarkan penelitian yang dilakukan pada kajian ini, } \\
\text { kota Cianjur telah menerapkan dua konsep kosmologis dalam dua } \\
\text { tataran, yaitu mikro dan makro. Di tataran mikro, yang meliputi pusat } \\
\text { kota, ditata dengan mengikuti kaidah kosmologis kota-kota Islam di } \\
\text { Jawa. Pola ini dapat dilihat dari keletakan masjid di barat alun-alun, } \\
\text { pendopo atau pusat pemerintahan di selatan alun-alun yang sekaligus } \\
\text { membelakangi suatu sungai kecil. Penataan ruang yang terlihat di kota } \\
\text { Cianjur dalam tataran makro diketahui mengikuti pada kaidah konsep } \\
\text { tritangtu. }\end{array}$ \\
\hline
\end{tabular}




\section{PENDAHULUAN}

Kota-kota tradisional di Jawa pada umumnya memiliki penataan kota yang erat kaitannya dengan konsep kosmologis yang berkembang pada masanya. Sejak masa Majapahit, penataan kota secara teratur dengan mengikuti konsep kosmologis telah dijalankan, seperti yang dapat diamati di ibukota Majapahit di kawasan Trowulan. Ibukota Majapahit seakan dibentuk dalam tiga hirarki yang mengikuti konsep Sanga Mandala yang berasosiasi dengan pembagian lahan secara horizontal (Munandar, 2013, p. 68). Penataan kota pada masa Islam khususnya di Jawa, sedikit banyak mendapat pengaruh budaya Hindu-Buddha. Pusat kekuasaan atau kraton (yang biasanya ditempatkan di selatan alun-alun) ditempatkan berdekatan dengan masjid (biasanya berada di sebelah barat alunalun). Konsep penataan kota semacam ini menjadi representasi kedekatan raja terhadap kehidupan keagamaan (Nasution, 2014, p. 179).

Cianjur adalah satu kabupaten di Jawa Barat yang kaya akan data arkeologis berupa unsur-unsur dasar dari kota tradisional, seperti pendopo, pusat pemerintahan, masjid, alun-alun, pemukiman serta makam keramat. Selain itu Cianjur juga merupakan salah satu kota yang dibentuk oleh masyarakat asli Sunda dan bukan oleh pemerintah kolonial (Lubis et al., 2011, p. 28) Dengan demikian, kota ini dianggap sebagai purwarupa dari kota yang merepresentasikan budaya Sunda. Masyarakat Cianjur yang termasuk ke dalam rumpun etnis Sunda, secara tradisional juga memiliki konsep kosmologis tersendiri yang sifatnya unik atau berbeda dari konsep kosmologis di Jawa. Konsep kosmologis yang dikenal dalam masyarakat Sunda disebut sebagai Tritangtu. Konsep tritangtu merupakan suatu pola tiga universal yang dipercayai oleh masyarakat sunda di berbagai aspek kehidupan, yang mana dalam penelitian ini konsep tritangtu yang biasanya diaplikasikan pada tata kota merujuk pada tritangtu di buana. Konsep ini merujuk kepada kesatuan pucuk-pucuk kepemimpinan di Kerajaan Sunda yang dapat direpresentasikan dalam berbagai aspek kehidupan masyarakat Sunda. Pucuk kepemimpinan yang dimaksud antara lain prabhu (raja), rsi (pemimpin agama) dan rama (tetua adat). Ketiga aspek ini tidak dapat dipisahkan satu sama lain, karena berkaitan dengan keseimbangan alam (Munandar et al., 2011, p. 36; Sumardjo, 2009, pp. 103104). Konsep tritangtu secara jelas 
dipaparkan secara mendalam pada suatu baris kalimat dalam serat Siksa Kanda $n g$ Karesian yang berbunyi sebagai berikut:

"inilah tiga golongan dalam kehidupan. Inilah tiga ketentuan di dunia: wibawa kita bagaikan raja (prabhu), ucap kita ibarat rama (tetua), dan budi kita bagaikan resi. Itulah tritangtu di dunia; yang dianggap sebagai peneguh dunia" (Karlina et al., 1993, p. 34)

$$
\text { Jakob Sumardjo }
$$

menyebutkan bahwa konsep tritangtu amat luas pemaknaannya. Konsep segitiga ini saling keterkaitan satu sama lain, dan berlaku di pelbagai aspek kehidupan manusia. Konsep ini berlaku pada pembagian unsur alam, pembagian dewata dalam agama Hindu, pembagian kerja dalam kehidupan sosial dan berbagai aspek lainnya. Satu di antara banyak dari penerapan konsep tritangtu, Sumardjo memberikan suatu gambaran mengenai penerapan konsep tritangtu pada pola hunian Sunda, yang model huniannya diilustrasikan sebagai berikut (gambar 1):

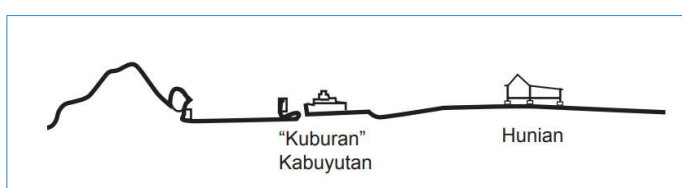

Gambar 1. Pola Hunian tradisional Sunda sesuai Konsep Tritangtu dari hulu ke hilir (Sumber: Sumardjo, 2009)

Penelitian mengenai penerapan konsep kosmologis Sunda pada kajian arkeologi pemukiman telah dilakukan beberapa peneliti, seperti Etty Saringendyanti (1996), Agus Aris Munandar et al. (2011), Muhammad Zaini Dahlan (2017), dan Garbi Cipta Perdana dan Wanny Rahardjo Wahyudi (2020). Penelitian sebelumnya yang menyinggung penerapan konsep kosmologis Sunda, lebih banyak berfokus kepada datum situs sakral, seperti kabuyutan atau bangunan suci lain. Penelitian yang berusaha merekonstruksi penerapan konsep kosmologis Sunda pada tata kota di Jawa Barat, belum pernah dilakukan oleh peneliti sebelumnya.

Tujuan dari penelitian ini adalah untuk merekonstruksi akan adanya kemungkinan keberlanjutan budaya dari kepercayaan masyarakat pra-Islam di masa Islam-Kolonial, khususnya di Kota Cianjur. Penelitan ini secara khusus membahas tata kota Cianjur, dengan permasalahan mengenai bagaimana kaitan antara penataan kota Cianjur sebagai salah satu kota yang merepresentasikan budaya Sunda dan konsep kosmologis Tritangtu, baik secara mikro maupun makro?

Penelitian ini berfokus pada pembagian ruang pada suatu kota dan kaitannya akan suatu konsep tertentu, dasar paradigma yang digunakan dalam penelitian ini adalah arkeologi pasca- 
prosesual. Arkeologi pasca-prosesual merupakan gerakan pemikiran dalam arkeologi yang menentang pemikiran postivisme dalam arkeologi. Pemikiran ini menolak adanya suatu kebenaran objektif yang dianggap universal oleh masyarakat yang bersifat hakiki dalam menafsirkan data arkeologi. Paradigma ini kemudian sering dikaitkan dengan pemfokusan kajian arkeologi pada proses pemaknaan (Johnson, 2020, p. 112). Kajian arkeologi pasca-prosesual melihat tinggalan budaya sebagai suatu sistem simbol yang disepakati secara bersama-sama oleh masyarakat dan didasari oleh akumulasi kognisi manusia (Sunliensyar, 2017, p. 53). Pada konteks arkeologi keruangan, paradigma pasca-prosesual telah mengartikan suatu ruang sebagai kesatuan dengan individu yang beraktivitas di dalamnya dan memiliki nilai makna tersendiri. Makna dari suatu ruang muncul apabila ruang tersebut memiliki kaitan khusus dengan aktivitas yang dilakukan manusia, sehingga manusia memproduksi nilai-nilai tersendiri akan ruang tersebut dengan media kognisi dan emosi (Perdana \& Wahyudi, 2020, p. 2; Tilley, 1994, pp. 10-15).

Penelitian ini secara umum diharapkan mampu menjadi gambaran perancangan tata kota tradisional Cianjur dalam perspektif Arkeologi Perkotaan. Hasil dari penelitian ini di sisi lain dapat menginformasikan proses evolusi yang terjadi dari pengetahuan masyarakat Sunda di Cianjur yang beralih dari masa Hindu-Buddha ke masa Islam-Kolonial. Dengan demikian didapatkan suatu pemahaman besar akan adanya proses pelanjutan tradisi yang terjadi pada kasus tata kota Cianjur, sehingga dapat menjadi bahan berkontemplasi masyarakat Sunda di masa sekarang dan masa depan akan kearifan nenek moyang masa lampau.

\section{METODE}

Metode yang diterapkan dalam proses kajian ini adalah metode penelitian arkeologi. Metode penelitian tersebut terdiri dari tiga tahapan, yaitu proses pengumpulan data (observasi), analisis dan interpretasi (Sharer \& Ashmore, 2003). Tahapan pengumpulan data dilakukan melalui studi kepustakaan terhadap penelitian-penelitian sebelumnya mengenai sejarah perkotaan Cianjur dan perekaman data lapangan secara langsung terhadap unsur-unsur infrastruktur kota yang paling awal dibangun, yaitu pendopo, masjid, alun-alun, dan makam keramat, serta pasar dan/atau pecinan. Data yang terkumpul kemudian dianalisis secara deskriptif-komparatif, yaitu melalui pengklasifikasian unsur-unsur 
pada data penelitian yang berkaitan dengan pertimbangan penempatan atau penataan kota, Unsur-unsur yang dimaksud sebagaimana yang disampaikan oleh Mundardjito (1993, p. 56), yaitu ketinggian dan kelerengan, kedekatan dengan sumber air, orientasi, dan asosiasi objek dengan lingkungannya. Deskripsi data tersebut lantas dibandingkan dengan kasus tata kota Islam di Jawa Barat yang lain, yang dalam penelitian ini dipilih Kota Cirebon. Penetapan Kota Cirebon sebagai data pembanding didasarkan pada kentaranya unsur-unsur yang mewakili tata kota Islam di kawasan Cirebon, sebagaimana telah dijelaskan oleh para ahli sebelumnya. Hasil dari analisis kemudian diinterpretasi melalui penerapan konsep Tritangtu yang menjadi konsep kosmologis masyarakat Sunda.

\section{HASIL DAN PEMBAHASAN}

\section{Gambaran Umum dan Sejarah}

Cianjur

Kabupatan Cianjur secara administratif terletak di Provinsi Jawa Barat yang berbatasan dengan Kabupaten Sukabumi, Bogor, Purwakarta, Bandung Barat, dan Garut. Kabupaten Cianjur membentang di atas lansekap seluas 361.434, 98 hektar (ha), dengan ketinggian rata-rata antara 7-2.962 meter di atas permukaan laut (mdpl; Pemkab
Cianjur, 2021). Wilayah Cianjur pada dasarnya sebagian besar menutupi kawasan kaki Gunung Gede. R.W. van Bemmelen (1949, p. 27) menyebutkan bahwa secara geologis, Cianjur termasuk ke dalam zona Pengunungan Priangan selatan. Zona pegunungan ini membentang dari Jampang di sebelah barat sampai ke daerah Nusa Kambangan di sebelah timur. Zona pegunungan ini bersinggungan dengan patahan zona Bandung.

Kota Cianjur (pusat Kabupaten Cianjur) dapat dikatakan sebagai salah satu kota tua di Jawa Barat, sebagaimana yang disebut dalam catatan Sajarah Cikundul. Tradisi sejarah lokal Cianjur tersebut menyebutkan bahwa Cianjur pertama kali didirikan oleh Kanjeng Raden Aria Wira Tanu Datar I (Dalem Cikundul) pada tahun 1677. Wira Tanu Datar I sebagaimana dikisahkan dalam Sajarah Cikundul merupakan putra dari Raden Aria Wangsa Goparana, seorang penyebar Islam di daerah Sagalaherang (Subang) sekaligus punggawa Kesultanan Cirebon dari daerah Talaga (Majalengka). Wira Tanu Datar I pertama kali membangun pemukiman perintis Cianjur di daerah Cikundul, yang sekarang masuk ke dalam daerah Kecamatan Cikalongkulon (sebelah utara Kabupaten 
Cianjur). Perintisan Cianjur oleh Wira

Tanu Datar I saat itu bermula dari perintah

Sultan Cirebon yang memerintahkan dirinya untuk mengawasi pergerakan Kerajaan Sumedang Larang yang menguat di Priangan Timur (Lubis et al., 2011, p. 29; Widiyanto et al., 1999, pp. 82-88).

Pasca mangkatnya Wira Tanu

Datar I, kekuasaan Cianjur dilanjutkan oleh Wira Tanu Datar II yang memindahkan pusat kekuasaan ke Ciranjang. Pusat kekuasaan kembali berpindah, sejak masa kekuasaan Wira Tanu Datar III (Dalem Condre). Wira Tanu Datar III memindahkan pusat kekuasaan Cianjur ke pusat kota Cianjur dewasa ini. Perpindahan ini ditandai dengan dibangunnya alun-alun, pendopo dan masjid agung secara bertahap pada sekitar akhir abad ke-19 Masehi (M; Lubis et al., 2011, p. 246).

\section{Lima Aspek Utama pada Tata Kota Kuno Cianjur \\ Pendopo Dalem Cianjur}

Pendopo secara garis besar merupakan kediaman bupati atau disebut Dalem Cianjur. Lokasi pendopo terletak di Jalan Siti Jenab, Kampung Kebon Kembang, Kelurahan Pamoyanan, Kecamatan Cianjur, Kabupaten Cianjur, Jawa Barat. Luas pendopo meliputi area sebesar 1.450 meter persegi $\left(\mathrm{m}^{2}\right)$. Pendopo ini dibangun di tengah-tengah kota, dengan arah hadap ke utara. Bangunan pendopo sekarang berbatasan dengan alun-alun di sebelah utara, Jalan Siti Jenab di sebelah barat, pemukiman dan pasar di sebelah timur dan sungai kecil di sebelah selatan. Pendopo Dalem Cianjur berada di ketinggian 446 mdpl.

Bangunan pendopo diperkirakan pertama kali berdiri pada masa pemerintahan Raden Wira Tanu Datar III di sekitar abad ke-17. Tahun 1779 bangunan pendopo mengalami kerusakan akibat bencana gempa. Bangunan pendopo kemudian dibangun ulang oleh Raden Wira Tanu Datar VI pada tahun 1780 (Dinas Pariwisata dan Kebudayaan Provinsi Jawa Barat, 2011; Widiyanto et al., 1999).

Bangunan pendopo Dalem Cianjur secara umum memiliki gaya percampuran antara gaya indies dan tradisional yang khas. Gaya indies bangunan dapat dilihat dari desain serambi bangunan yang menjorok ke depan dan keberadaan pilarpilar penyangga kanopi di muka bangunan dengan dominasi warna putih. Gaya indies juga dapat terlihat jelas dari bentuk ventilasi bangunan yang tinggi serta desain pintu yang relatif besar. Gaya tradisional pada bangunan pendopo diwakili dari bentuk ornamen ukiran pada 
fasad dan kanopi bangunan yang berpola segitiga runcing yang terbalik (mirip dengan ornamen rumah tradisional Betawi) dan pola seperti bentuk ombak. Bagian atap pendopo yang terbuat dari genting dan berbentuk limasan juga menjadi ciri gaya tradisional pada bangunan ini (gambar 2 dan 3 ).

$$
\text { Bangunan pendopo juga }
$$

dilengkapi dengan halaman belakang.

Bagian belakang pendopo disertai dengan beberapa objek yaitu kolam yang berbentuk persegi yang berukuran luas $1.350 \mathrm{~m} 2$ dan bangunan bale kambang di atasnya. Di bagian barat kolam terdapat bangunan yang berbentuk persegi panjang dengan atap limasan. Bagian utara dan timur kolam dibatasi dengan taman.

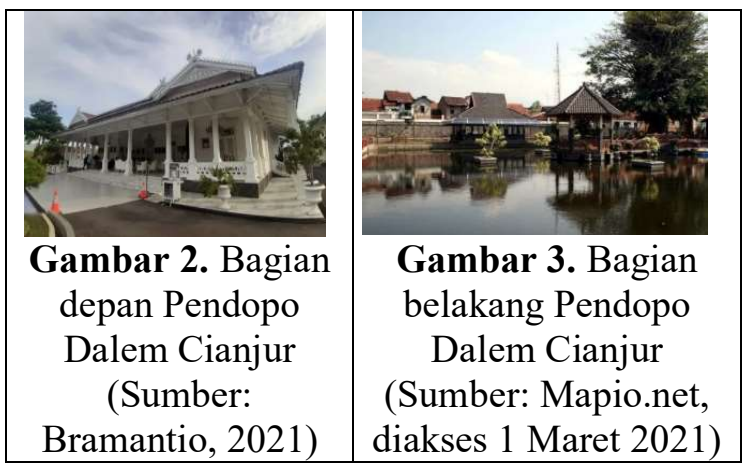

\section{Masjid Agung Cianjur}

Masjid Agung Cianjur berlokasi di Jalan Siti Jenab, Kelurahan Pamoyanan, Kecamatan Cianjur, Kabupaten Cianjur, Jawa Barat. Bangunan masjid berbatasan dengan alun-alun di timur, Kantor Pos
Cianjur dan Jalan Siti Jenab di selatan, Jalan Siti Boredar di utara dan pemukiman penduduk di barat. Masjid Agung Cianjur sekarang berukuran luas $3.300 \mathrm{~m} 2$. Gerbang utama masjid berorientasi ke timur, menghadap ke alun-alun Cianjur. Masjid Agung Cianjur berada di ketinggian 451 mdpl.

Bangunan Masjid Agung Cianjur pertama kali dibangun pada tahun 1810 secara bersama-sama oleh masyarakat Cianjur. Masjid ini didirikan di atas tanah wakaf milik Raden Ayu Siti Boredar. Perbaikan pertama bangunan masjid dilakukan oleh Raden Adipati Aria Prawiradiredja I pada tahun 1820. Masjid kemudian mengalami kerusakan parah akibat gempa yang melanda Cianjur di tahun 1879. Penghulu agung (Hoofdepenghoeloe) Cianjur bernama Raden Aria Soelaiman beserta tokoh Cianjur bernama Raden Haji Ma'moen berupaya membangun kembali Masjid Agung di tahun berikutnya. Di zaman kekuasaan Raden Adipati Aria Wiranatakusumah $\mathrm{V}$, bangunan masjid direnovasi kembali dan bahkan diperluas. Renovasi terakhir masjid baru dilakukan kembali pada pasca-kemerdekaan, tepatnya pada tahun 1998 (Ayuningdiah, 2017, p. A444; Rachman, 2016, p. 5). 
Gaya bangunan Masjid Agung Cianjur yang sekarang lebih didominasi dengan gaya timur tengah dan mendapat sentuhan gaya tradisional Priangan. Bangunan masjid yang sekarang terdiri dari satu bangunan dengan empat menara. Atap bangunan berbentuk tumpang dengan tiga tingkatan yang berbentuk piramida dan berbahan dasar genting. Kemuncak atap dilengkapi dengan memolo atau mestaka. Atap menara memiliki bentuk yang serupa pula dengan atap bangunan utama, namun bedanya dasar piramida atap menara berbentuk oktagonal. Bangunan masjid memiliki tiga akses pintu yang berada di sisi selatan, timur, dan utara. Masing-masing pintu dihiasi dengan ornamen kaca patri di bagian atasnya. Bagian dalam masjid terdiri dari dua lantai, yang bagian mihrab dan mimbarnya berada di sisi barat (menghadap kiblat).

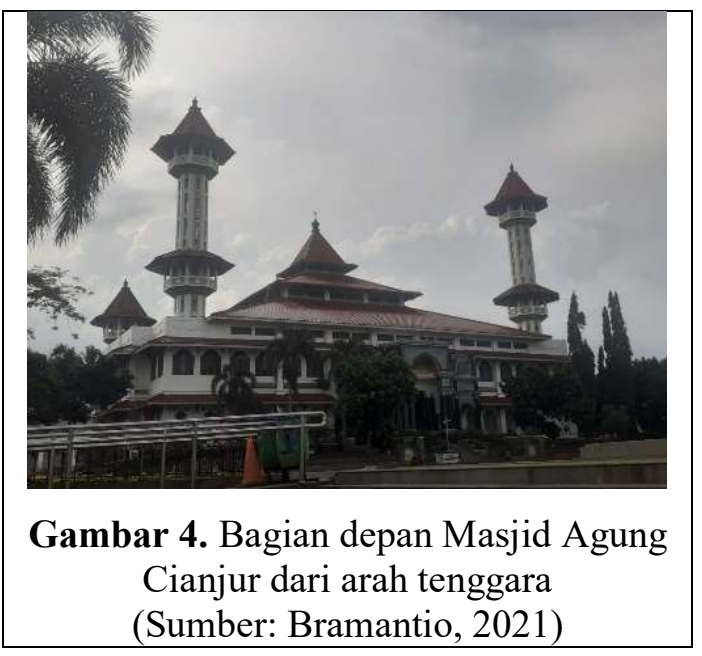

\section{Alun-alun}

Alun-alun Cianjur terletak di Jalan Siti Jenab, Kelurahan Pamoyanan, Kecamatan Cianjur, Kabupaten Cianjur, Jawa Barat. Alun-alun Cianjur berbatasan dengan Masjid Agung Cianjur di bagian barat, Jalan Siti Boredar di utara, Jalan A. Hanapiah di timur, dan Pendopo Dalem Cianjur di selatan. Alun-alun Cianjur sekarang memiliki bentuk persegi dengan ukuran 75 m x 75 m. Keadaan alun-alun Cianjur sekarang merupakan area lapang yang dihampari dengan rumput sintetis yang dilengkapi dengan tugu Alquran, kolam, dan air mancur yang menghiasi bagian tengah alun-alun. Ketinggian kontur dari alun-alun Cianjur adalah 449 mdpl.

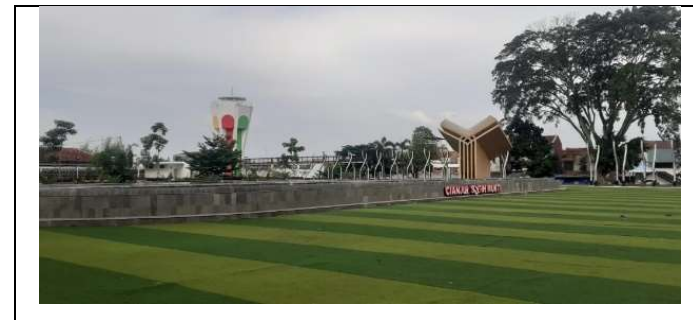

Gambar 5. Alun-alun Cianjur (Sumber: Bramantio, 2021)

Pembangunan awal alun-alun dirintis oleh Raden Wira Tanu Datar III yang merupakan suatu kesatuan dengan Masjid Agung Cianjur dan Pendopo Dalem Cianjur. Alun-alun difungsikan sebagai ruang publik yang menjadi media 
tempat pertemuan berbagai kalangan masyarakat, tempat penyelenggaraan upacara keagamaan, serta lokasi pertunjukkan seni ataupun tempat berlatih militer (Widiyanto et al., 1999).

\section{Makam Dalem Cikundul}

Makam Dalem Cikundul terletak

di Kelurahan Cijagang, Kecamatan Cikalongkulon, Kabupaten Cianjur, Jawa Barat. Makam Dalem Cikundul berbatasan dengan pepohonan rindang di bagian barat, utara, timur, dan pemukiman warga di selatan. Tempat ini merupakan makam Bupati Cianjur yaitu Raden Wira Tanu Datar I bin Aria Wangsa Goparna. Makam terletak di dalam bangunan dengan luas $300 \mathrm{~m} 2$ di atas tanah seluas 4 ha di puncak Bukit Cijagang yang dapat diakses melalui anak tangga. Makam Dalem Cikundul secara keseluruhan telah direnovasi dalam bentuk bangunan makam modern yang dinaungi bangunan modern pula.

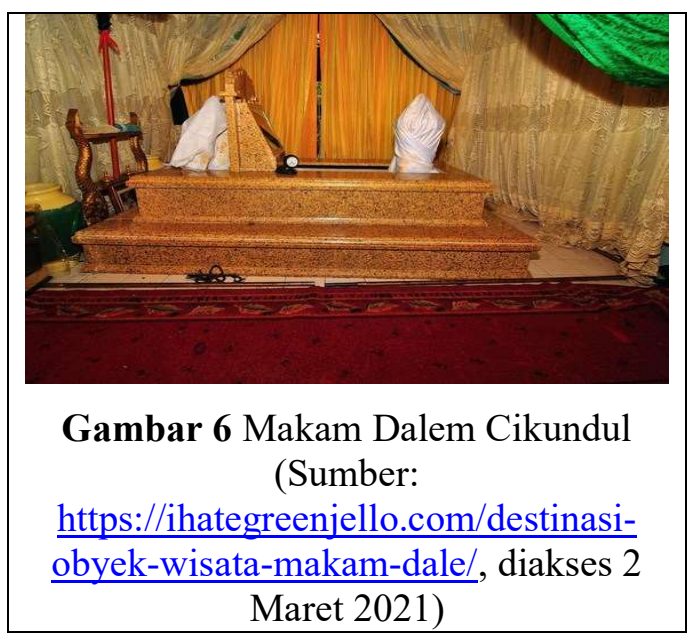




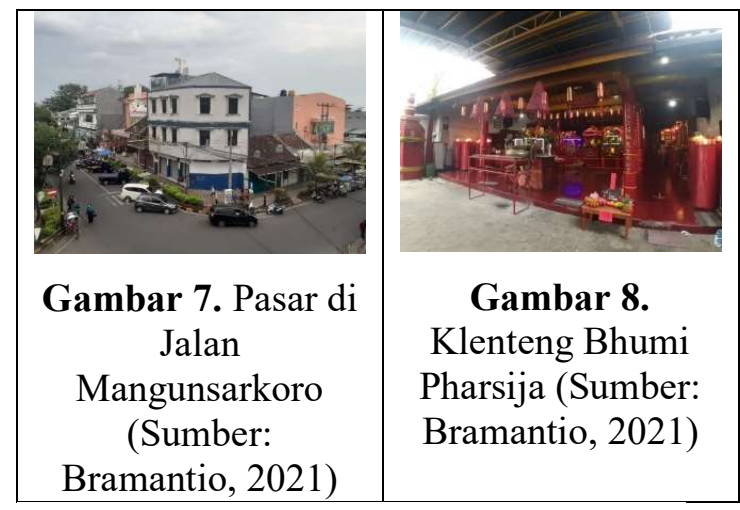

Tabel 1. Tata Letak Lima Aspek Utama Tata Kota Kuno Cianjur

\begin{tabular}{|c|c|c|c|c|}
\hline Nama Objek & $\begin{array}{l}\text { Lokasi (Kelurahan, } \\
\text { Kecamatan, } \\
\text { Kabupaten) }\end{array}$ & $\begin{array}{l}\text { Ketinggian } \\
\text { (mdpl) }\end{array}$ & Orientasi & $\begin{array}{l}\text { Lingkungan atau keterkaitannya } \\
\text { dengan objek lain }\end{array}$ \\
\hline $\begin{array}{l}\text { Pendopo Dalem } \\
\text { Cianjur }\end{array}$ & $\begin{array}{l}\text { Pamoyanan, } \\
\text { Cianjur, Cianjur }\end{array}$ & 446 & Utara & $\begin{array}{l}\text { Berada di selatan alun-alun dan } \\
\text { tenggara masjid agung }\end{array}$ \\
\hline Masjid Agung Cianjur & $\begin{array}{l}\text { Pamoyanan, } \\
\text { Cianjur, Cianjur }\end{array}$ & 451 & Timur & $\begin{array}{l}\text { Berada di barat alun-alun dan barat } \\
\text { laut pendopo }\end{array}$ \\
\hline Alun-alun Cianjur & $\begin{array}{l}\text { Pamoyanan, } \\
\text { Cianjur, Cianjur }\end{array}$ & 449 & - & $\begin{array}{l}\text { Berada di utara pendopo dan timur } \\
\text { masjid agung }\end{array}$ \\
\hline $\begin{array}{l}\text { Makam Keramat } \\
\text { Dalem Cikundul }\end{array}$ & $\begin{array}{l}\text { Cijagang, } \\
\text { Cikalongkulon, } \\
\text { Cianjur }\end{array}$ & 428 & - & $\begin{array}{l}\text { Berada di luar inti kota, berjarak } 17 \\
\text { km ke arah utara/ timur laut dari } \\
\text { pusat kota. }\end{array}$ \\
\hline $\begin{array}{l}\text { Pasar dan pecinan } \\
\text { Cianjur }\end{array}$ & $\begin{array}{l}\text { Pamoyanan, } \\
\text { Cianjur, Cianjur }\end{array}$ & 443 & - & $\begin{array}{l}\text { Berdekatan dengan alun-alun dari } \\
\text { sisi timur laut. }\end{array}$ \\
\hline
\end{tabular}

Sumber: Alnoza dan Bramantio, 2021

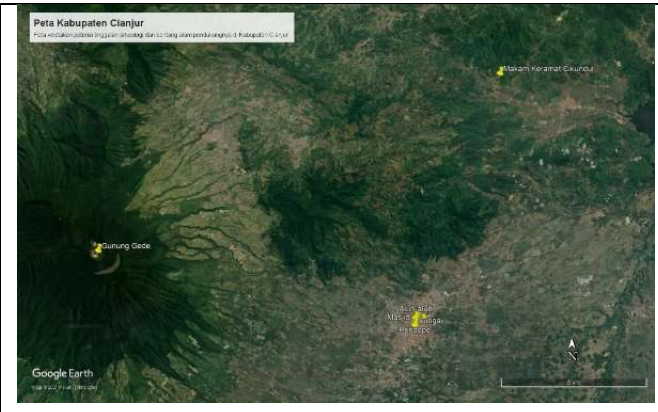

Gambar 9. Peta Kabupaten Cianjur dan persebaran lima aspek utama tata kota kuno Cianjur (Alnoza dan Bramantio diolah melalui Google Earth, 2021)

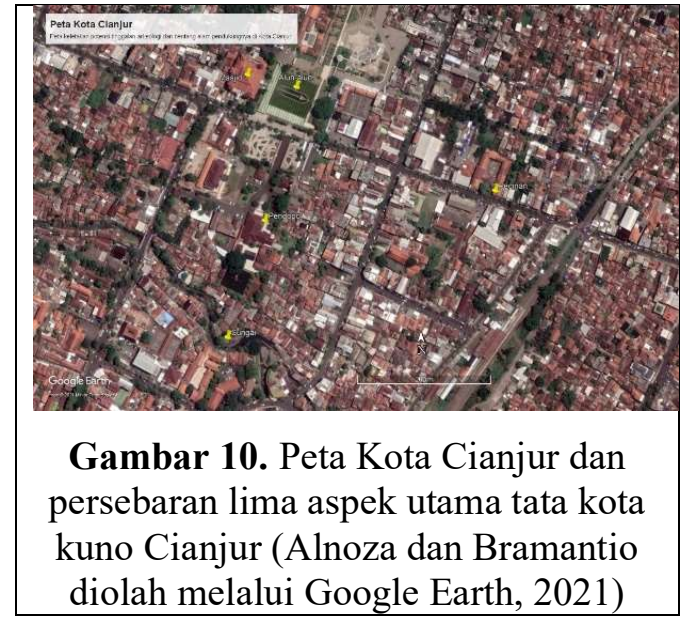




\section{Tata Kota Kuno pada Skala Mikro dan Makro}

Penelitian ini secara umum melihat pembagian tata kota Cianjur ke dalam dua kategori, yaitu kategori mikro dan makro. Pembagian ini didasarkan pada kenyataan bahwa adanya perbedaan karakteristik dan gejala yang muncul pada tataran mikro dan makro. Tataran mikro yang dimaksud adalah meliputi wilayah Cianjur di bagian pusat kota, sedangkan tataran makro yang dimaksud dari kajian ini meliputi seluruh wilayah Kabupaten Cianjur. Berikut interpretasi yang dapat diberikan pada tata kota Cianjur, baik secara mikro maupun makro.

\section{Tata Kota Cianjur Skala Mikro}

Pusat kota Cianjur dalam hal ini meliputi wilayah sekitaran alun-alun, pendopo, pasar dan masjid agung yang memiliki banyak kemiripan dengan tata kota di Jawa Tengah dan Timur. Contohnya seperti kota-kota pusat penyebaran Islam, misalnya Cirebon, Yogyakarta, Surakarta yang menerapkan konsep ini. Apabila diperbandingkan antara Cianjur dengan salah satu contoh kota yang telah disebutkan di atas, maka akan terlihat sebagai berikut (Gambar 11),

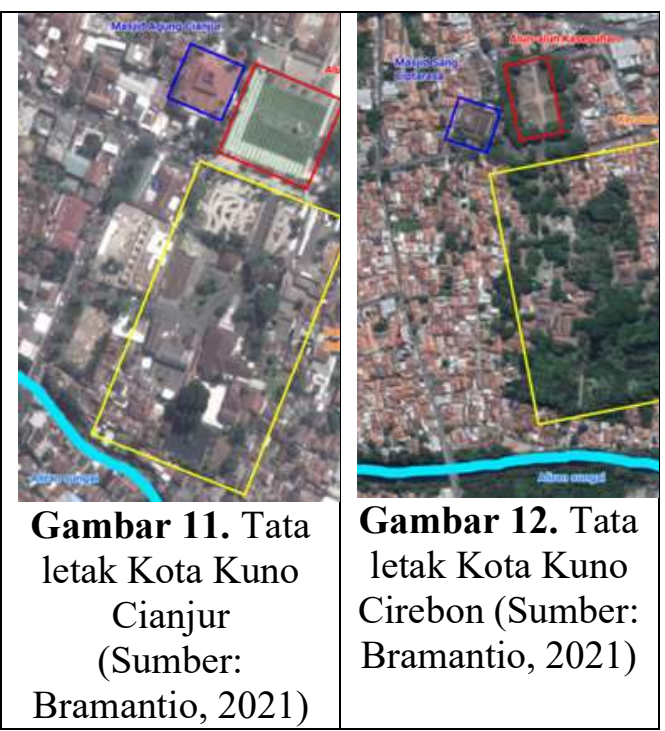

Sesuai dengan ilustrasi peta di atas (Gambar 11), Pendopo Dalem Cianjur (kotak warna kuning) yang dalam hal ini sebagai pusat kekuasaan perlu dipandang sebagai entitas yang sama dengan Kraton Kasepuhan Cirebon (kotak warna kuning gambar 12). Nina Herlina Lubis (2011, p. 8) menyebutkan bahwa pendopo dalam konteks budaya masyarakat Priangan merupakan tempat tinggal dan pusat kekuasaan dari seorang menak pangluhurna (bangsawan tertinggi) yang dalam hal ini bisa jadi seorang dalem atau bupati. Bupati atau dalem pasca keruntuhan Kerajaan Sunda seakan-akan telah menjadi penguasa tertinggi yang diakui secara lokal. Kraton di sisi lain juga berkedudukan sebagai kediaman penguasa tertinggi suatu kerajaan, yang dalam budaya Indonesia sering diartikan pula tempat bersemayamnya manusia 
setengah dewa. (Behrend, 1989, pp. 173174). Keduanya dengan demikian samasama dapat diartikan sebagai poros dari suatu kota kerajaan. Saat dibandingkan pada peta di gambar 11 dan 12 di atas, hampir semua aspek dalam peletakkan Pendopo Dalem Cianjur serupa dengan Kraton Kasepuhan Cirebon. Pendopo Dalem Cianjur dan Kraton Kasepuhan Cirebon sama-sama dibangun dengan letak membelakangi suatu sungai kecil, berorientasi ke utara dan berbatasan dengan alun-alun di utara. Kesamaan lainnya juga muncul pada peletakkan masjid agung yang sama-sama berada di sisi barat alun-alun. Pembeda dari kedua kota ini lebih terlihat pada keletakkan pasar dan arah orientasinya dari pendopo. Pasar di Cianjur menempati ruang di sebelah timur laut dari Pendopo Dalem Cianjur, sedangkan di Cirebon pasar berada di sebelah utara dari kraton kasepuhan.

Banyaknya kesamaan antara tata pusat kota Cirebon dan Cianjur ini bukan menjadi hal yang aneh. Data sejarah memberikan penjelasan mendasar mengenai keberadaan fenomena ini. Menurut Nina Herlina Lubis et al. (2011, 29), agama dan budaya Islam di Cianjur diperkirakan bermula dari Cirebon dan dibawa oleh Raden Aria Wangsagoparana yang berasal dari Majalengka. Adapun Lubis dkk. menduga ada suatu jalur difusi kebudayaan Islam melalui CirebonTalaga (Majalengka) - Sagalaherang (Subang) - Cianjur. Penataan kota di Cirebon sendiri dipercaya berasal dari ajaran seorang warga Majapahit bernama Raden Sepet yang menetap di Cirebon. Raden Sepet ini lah yang membantu Sunan Gunung Jati dalam membangun Kota Cirebon (Tjandrasasmita, 2009, p. 171). Pengaruh konsep penataan kota Islam-Jawa yang berasal dari Cirebon ini menjadi hal yang mungkin sekali dibawa oleh Dalem Cikundul, kendati demikian penerapannya baru diterapkan oleh penerusnya sehingga dapat diterapkan pada konsep penataan kota Cianjur pada saat itu (hingga saat ini belum ditemukan bukti penerapan konsep ini di Cikundul). Penataan kota semacam ini juga dapat dianggap sebagai simbol legitimasi Cianjur sebagai suatu kota Islam di masanya.

Bentang alam yang dapat diamati pada konteks ruang tata kota Cianjur dalam skala mikro, pada dasarnya berguna bagi keberlangsungan kegiatan masyarakat di pusat kota Cianjur. Sumber air berupa aliran sungai di selatan pendopo misalnya, dapat dimanfaatkan oleh warga dan kedudukannya di awasi langsung oleh 
penguasa tertinggi yaitu Bupati. Begitu pula dengan desain pusat kota yang berdataran rendah, sengaja dimanfaatkan untuk keperluan efisiensi akses masuk kota. Kemudahan akses ini nantinya berdampak pada kelancaran kegiatan perekonomian dan sosialisasi kekuasaan.

\section{Tata Kabupaten Cianjur Skala Makro}

Pola hunian yang digambarkan pada gambar 1 dapat dikatakan mirip dengan karakteristik kontur keletakan objek-objek fitur arkeologis di Cianjur. Komponen-komponen pada model yang dibuat oleh Sumardjo (2009), dapat ditemui pula pada wilayah Kabupaten Cianjur. Oleh karena itu, dapat diinterpretasikan bahwa: (i) objek hunian pada model di gambar 1 dapat disamakan dengan pusat kota Cianjur; (ii) kuburan atau kabuyutan dapat diasosiasikan dengan makam keramat Dalem Cikundul; dan (iii) dataran tinggi dapat disamakan pula dengan Gunung Gede yang ada di wilayah Kabupaten Cianjur. Ketinggian masing-masing komponen juga dapat dianggap sama, karena faktanya makam keramat Dalem Cikundul memang lebih rendah daripada pusat kota Cianjur dan Gunung Gede merupakan titik tertinggi di wilayah Cianjur (gambar 9). Secara horizontal ketiga komponen juga membentuk suatu garis imajiner yang berbentuk segitiga (gambar 10).

$$
\text { Gejala-gejala yang muncul }
$$

sebagaimana ditunjukkan di atas membawa pada suatu interpretasi mengenai status dari tiap-tiap komponen fitur arkeologis dan bentang alam yang digunakan sebagai data dalam penelitian ini. Pada tataran ini, Gunung Gede dapat ditafsirkan sebagai objek yang berstatus sebagai rama (tetua adat). Postulat ini didasarkan pada kepercayaan masyarakat Sunda yang menganggap gunung-gunung sebagai tempat bersemayam para leluhur yang tidak lagi berwujud. Gunung Gede pada khususnya dianggap sebagai gunung kuno. Selain itu, sebagaimana disebutkan dalam naskah Bujangga Manik bahwa pada masa pra-islam, pernah berdiri suatu kabuyutan bagi pemujaan Sang Hyang Talaga Warna (Sunjana, 2019, p. 101). Meskipun kabuyutan ini pada masa Islam tidak pernah disebutkan (dalam naskah zaman Islam), dapat dipastikan pula bahwa Gunung Gede tetap dianggap sebagai tempat bersemayamnya nenek moyang yang memiliki sifat bijak. Argumentasi ini didasarkan pada keterangan di naskah Sajarah Cikundul yang menyebut bahwa salah satu nenek moyang mereka yang bernama Raden Mas Surya Kencana bersemayam di Gunung 
Gede (Widiyanto et al., 1999, p. 53). Sumber lain dalam hal ini Amanat Galunggung, juga menyebutkan bahwa rama adalah entitas yang bertanggung jawab akan kemakmuran (Munandar et al., 2011, p. 35). Apabila cara pandang ini diasosiasikan dengan gunung, tidak berlebihan untuk menyetarakan gunung sebagai rama, karena memang dasarnya gununglah yang memberikan sumber kemakmuran bagi wilayah di sekitarnya.

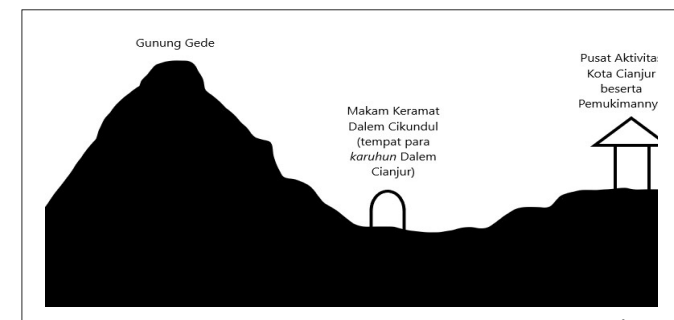

Gambar 13. Penataan ruang sesuai dengan ketinggian tertentu di Kabupaten Cianjur yang mengikuti kaidah pada konsep Tritangtu

(Sumber: Alnoza, 2021)

Makam Dalem Cikundul dalam hal ini bisa diposisikan sebagai entitas rsi (pemimpin keagamaan). Dasar dari postulat ini adalah kenyataan bahwa makam ini merupakan tempat dikuburkannya orang yang menyebarkan agama Islam di Cianjur yaitu adalah Raden Aria Wira Tanu Datar I (Dalem Cikundul). Tokoh tersebut seakan masih mampu memberikan ketenangan duniawi bagi masyarakat, mengingat banyaknya orang yang berziarah untuk mencari berkah di tempat tersebut (Suganda et al., 2011, pp. 49-51). Dalem Cikundul juga erat kaitannya dengan proses penyebaran agama Islam di Cianjur, sehingga kedudukannya jelas sekali sebagai seorang pemuka keagamaan (seperti seorang resi dalam Agama Hindu).

Pusat Kota Cianjur beserta isinya dapat dianggap sebagai entitas prabhu dalam konteks tata kabupaten Cianjur. Pusat kota sebagai pusat pemerintahan dari seorang dalem atau bupati jelas merepresentasikan entitas prabhu sebagai pengayom masyarakat. Pusat kota Cianjur erat kaitannya dengan legitimasi, sehingga bisa diasosiasikan dengan sifat prabhu yang memiliki wibawa.

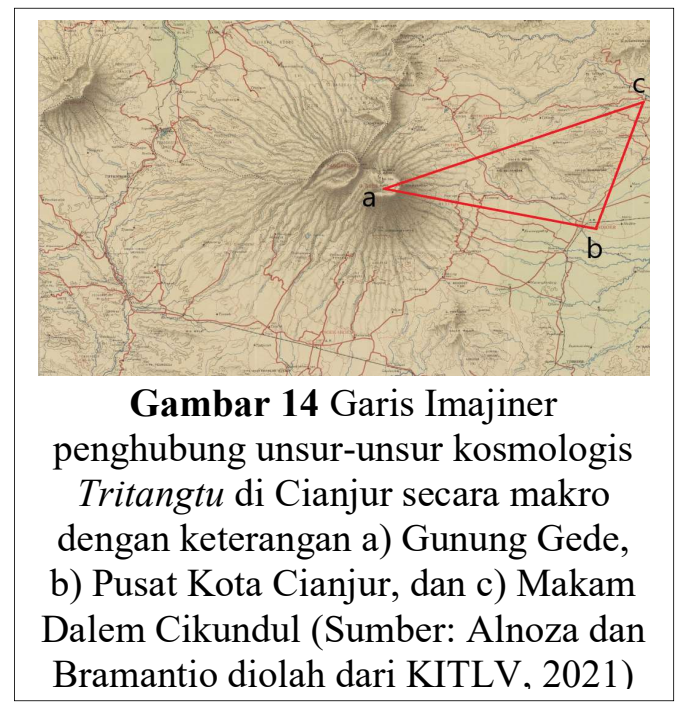

Secara keseluruhan, pola tiga yang ditemukan di Cianjur ini membentuk suatu kesatuan yang harmonis. Sebagaimana disebutkan dalam Naskah Siksa Kandang Karesian, pola tritangtu di buana 
memiliki makna porsi-porsi dalam dinamika kehidupan manusia. Artinya pembagian tata kota di Kabupaten Cianjur bermaksud hal yang demikian pula, dimana tiap bentang alam memiliki makna ruangnya masing-masing. Tiap-tiap ruang tersebut secara lebih lanjut dapat dipandang sebagai simbol segregasi tata ruang antar kelompok sosial di Cianjur.

\section{PENUTUP}

Cianjur pada akhirnya dapat dianggap sebagai suatu kota yang memiliki karakteristik tata kota yang memadukan konsep kosmologis asli Sunda dan konsep kosmologi Islam-Jawa yang berakar dari kebudayaan Majapahit. Sejarah panjang dari pendirian kota Cianjur (abad ke-17-19 M) hingga sekarang, serta kemauan untuk mempertahankan identitas, menjadi faktor yang terelakan dari fenomena tata kota yang terjadi di Cianjur. Peran Raden Aria Wira Tanu Datar I sebagai agen kebudayaan bisa dianggap juga sebagai salah satu faktor pendukung dari keberagaman penerapan konsep tata kota di Cianjur.
Fenomena yang terjadi di Cianjur juga menunjukkan bahwa telah terjadi keberlanjutan kebudayaan Sunda Kuno di zaman Islam-Kolonial. Konsep penataan kota atau dalam hal ini hunian khas Sunda, kota atau dalam hal ini hunian khas Sunda,

tidak semata-mata ditinggalkan oleh masyarakat Cianjur. Penerapan konsep tritangtu di Cianjur membuktikan bahwa masyarakat Cianjur pada masa Islam masih memegang teguh konsep yang berorientasi pada harmonisasi alam. Gunung Gede dianggap sebagai entitas rama karena merupakan sumber kemakmuran bagi masyarakat Cianjur. Makam Dalem Cikundul dianggap sebagai entitas rsi karena merupakan tempat paling awal disebarkannya ajaran Islam di Cianjur, serta tempat dikuburkannya ulama sekaligus umara paling kharismatik dalam sejarah Cianjur. Pusat kota dianggap sebagai entitas prabhu, karena merupakan tempat berdiamnya penguasa Cianjur dari generasi ke generasi. Ketiganya tidak dapat dipisahkan karena bentuk dari pengejewantahan kuasa Tuhan yang Maha Esa. Di sisi lain upaya memodifikasi dengan masuknya budaya baru (dalam hal ini budaya Islam) justru membentuk suatu corak baru dalam kebudayaan Cianjur itu sendiri.

Berdasarkan penelitian yang
dilakukan, dapat diketahui bahwa
masyarakat Cianjur pada masa Islam-
Kolonial melanjutkan tradisi masa
sebelumnya yang oleh mereka dirasa
Berdasarkan penelitian yang 
menguntungkan. Adapun konsep tritangtu yang pada masa sebelumnya berkembang tetap dipertahankan sebagai suatu kearifan lokal yang bermanfaat bagi pembagian makna ruang tempat mereka tinggal. Dengan demikian pada dasarnya, hasil penelitian ini dapat menjadi bahan kontemplasi bagi masyarakat Sunda pada khususnya dan Indonesia pada umumnya, untuk tetap mempertahankan nilai-nilai kearifan lokal leluhur dalam menghadapi dinamika zaman.

\section{DAFTAR PUSTAKA}

Ayuningdiah, A. (2017). Pengaruh Belanda dalam Arsitektur Masjid Agung di Priangan 1800 - 1942. Seminar Ikatan Peneliti Lingkungan Binaan Indonesia (IPLBI, A441A448. https://doi.org/10.32315/sem.1.a441

Behrend, T. E. (1989). Kraton and Cosmos in Traditional Java. Archipel, 37(2), 173-187.

Dahlan, M. Z. (2017). Kabuyutan Sacred Sites in The Sundanese Landscape of Indonesia: A Reevaluation From The Perspective of Sustainable Landscapes Management. Kyoto University.

Dinas Pariwisata dan Kebudayaan Provinsi Jawa Barat. (2011). Pendopo Kabupaten Cianjur. Disparbud.Jabarprov.Go.Id.

Johnson, M. (2020). Archaeology Theory: an Introduction (3rd Edition). Wiley Blackwell.

Karlina, N., Yunus, A., Rosyadi, \& Ganda, Y. (1993). Serat Siksa Kanda Karesian. Bagian Proyek Penelitian dan Pengkajian Kebudayaan Nusantara.

Kustedja, S. (2012). Jejak Komunitas Tionghoa dan Perkembangan Kota Bandung. Jurnal Sosioteknologi, 26(11), 105-128.

Lubis, N. H., Muhsin, M., Saringendyanti, E., Darsa, U. A., Kusdiana, A., Hernawan, W., \& Falah, M. (2011). Sejarah Perkembangan Islam di Jawa Barat. Universitas Padjajaran. Munandar, A. A. (2013). Tak ada Kanal di Majapahit. Wedatama Widyasastra.

Munandar, A. A., Fahrudin, D., Sujai, A., \& Rahayu, A. (2011). Bangunan Suci Sunda Kuna. Wedatama Widyasastra.

Mundardjito. (1993). Pertimbangan Ekologi dalam Penempatan Situs Masa Hindu-Buda di Daerah Yogyakarta: Kajian Arkeologi-Ruang Skala Makro. Universitas Indonesia.

Nasution, I. P. (2014). Masjid Kerajaan di Indonesia abad 16-21 Masehi sebagai Representasi Kuasa. Universitas Indonesia. 
Pemkab Cianjur. (2021). Letak Geografis. Cianjurkab.Go.Id.

Perdana, G. C., \& Wahyudi, W. R. (2020). Rekonstruksi Lanskap Kabuyutan Bandung Utara. PURBAWIDYA: Jurnal Penelitian Dan Pengembangan Arkeologi, 9(1), 1-14. https://doi.org/10.24164/pw.v9i1.317

Rachman, Y. (2016). Perkembangan Masjid Agung Cianjur 1956-1998. Universitas Padjajaran.

Saringendyanti, E. (1996). Penempatan Situs Upacara Masa Hindu-Buda: Kajian Lingkungan Fisik Kabuyutan di Jawa Barat. Universitas Indonesia.

Sharer, R. J., \& Ashmore, W. (2003). Archaeology:Discovering Our Past. McGraw-Hill Publishers.

Suganda, D., Dienaputra, R. D., Skober, T. R., Sofianto, K., Yuniadi, A., Nugrahanto, W., Kartika, N., \& Rahman, F. (2011). Visualisasi Tinggalan Sejarah Islam di Tatar Sunda 1600-1942 (edisi Priangan). Universitas Padjajaran dan Kementrian Pendidikan dan Kebudayaan.

Sumardjo, J. (2009). Kosmologi dan Pola Tiga Sunda. Imaji, 4(2), 101-110.

Sunjana, D. (2019). Mountain as Religious Site and Scriptoria during Ancient Sunda Period. $8(21), 97-111$.

Sunliensyar, H. H. (2017). Menggali Makna Motif Hias Bejana Perunggu Nusantara: Pendekatan Strukturalisme Levi-Strauss. Berkala Arkeologi, 37(1), 51-68.

Tilley, C. (1994). Summary for Policymakers. In Intergovernmental Panel on Climate Change. In C. Tilley (Ed.), A phenomenology of landscape: places, paths, and monuments (pp. 1-30). Cambridge University Press.

Tjandrasasmita, U. (2009). Kesultanan Cirebon: Tinjaun Historis dan Kultural. In Arkeologi Islam Nusantara (pp. 159-176). Kepustakaan Populer Gramedia dan EFEO.

van Bemmelen, R. W. (1949). The Geology of Indonesia: General Geology of Indonesia and Adjacent Archipelagos Vol.1a. Martinus Nijhoff.

Widiyanto, Y. S., Kusumah, S. D., Gurning, E. T., \& Purnama, Y. (1999). Sajarah Cikundul: Kajian Sejarah dan Nilai Budaya. Proyek Pengkajian dan Pembinaan Nilai-nilai Budaya Jakarta Direktorat sejarah dan Nilai Tradisional Direktorat Jenderal Kebudayaan Departemen Pendidikan dan Kebudayaan. 